\title{
Effect of alimentary synthetic estrogen on cell compensatory mechanisms in rats of different ages
}

Oleh Yermishev ${ }^{1}$,

Tatyana Lykholat ${ }^{2}$,

Olena Lykholat ${ }^{2^{*}}$

${ }^{1}$ Vasyl Stus Donetsk National University, 600-richya St. 21,

21021 Vinnitsa, Ukraine

${ }^{2}$ Oles Honchar Dnipropetrovsk National University, Haharina Ave. 72, 49000 Dnipropetrovsk, Ukraine
Results of a study of lipid peroxidation, antioxidant system components, and cholinergic neurotransmitter system in the organs of experimental rats of different ages exposed to alimentary synthetic estrogen are presented. Given the state of peroxidation processes and AChE activities in female rats exposed to xenoestrogen, it is possible to assume the possibility of the restructuring of the functioning of mediator and enzyme systems and additional strengthening of pathological symptoms. In the future, such phenomena may trigger the reduction of potential of compensatory mechanisms in compromising the health of the consumers. In puberty, females were more sensitive to nutritional synthetic estrogen than mature animals, thus proving that age is another factor in xenoestrogen exposure. Because of the changes in the rates of reactions to detoxification but not to the metabolism of estrogen received into the organism, particularly with food, with age the animals were less susceptible to the effects of these substances.

Keywords: xenoestrogen, lipid peroxidation, antioxidant system, cholinergic regulation, age

\section{INTRODUCTION}

Many contaminants are associated with their potential estrogenic effect and classified as endocrinedisrupting compounds, including numerous classes of organic compounds. Substances-depleted endocrine systems are a compound changing the hormonal and homeostatic system and acting through different mechanisms (Darbre, Charles, 2010).

Estrogens are female sex hormones produced by the follicles of the ovaries, placenta, partially adrenal cortex, and the testes. They regulate specific sexual functions. Estrogens spread through

${ }^{*}$ Corresponding author. E-mail: lykholat2010@ukr.net the bloodstream to various tissues, including the cardiovascular, the immune, and the central nervous systems. Due to their lipophilic character they can easily diffuse through cell membranes and hematoencephalic barrier exerting effects (Petrone et al., 2014). Estrogens may lead to structural changes in the body, including a modulation of mitochondrial ATP synthesis and of the scope of protein biosynthesis (Shearwood et al., 2015). The activity of steroid hormones is targeted at the brain. They can influence the architecture and plasticity of the brain, the neurochemical and molecular processes, as well as the behaviour and neural protection through genomic and non-genomic action. These processes are important for brain activity (McEwen, 2014). 
Xenoestrogens are industrial chemicals (for example, esters of phthalic acid, bisphenol A, phenolic compounds, and parabens) used in the manufacture of polycarbonate plastics, epoxy resins, food packaging and coatings, dental sealants, rubber chemicals, and flame retardants (Arditsoglou, Voutsa, 2008; Meulenberg, 2009; Boberg et al., 2010; Rochester, 2013). Similar compounds are present in antimicrobial substances (zearalenone) and medicines, personal hygiene products (Wielogórska et al., 2015), drinking and bottled water (Dhaini, Nassif, 2014), foods - grains, fruits and vegetables (Massart, Saggese, 2010), animal products - meat, dairy, eggs (Kolf-Clauw et al., 2008; Wielogorska et al., 2014). A special group is food containing phytoestrogens (Tomar, Shiao, 2008). Xenobiotic substances are contained in food (inhibitors of proteolytic enzymes) originally or through contamination with herbicides, pesticides, animal growth regulators, etc., some of which can form during improper cooking (roasting or smoking) (Hulin et al., 2014). Despite strict EU laws on the need of ensuring the safety of supply in view of low concentration levels of residual pesticides, the threat of pesticide residues exists in baby food (Hercegová et al., 2007). Such nutritional factors as phytoestrogens are contained in food, and legumes are particularly rich in them (Cassidy, 2003).

Consumers are put at the risk of low levels of exposure to these substances throughout their lives. At least half of these substances are resistant to natural degradation. The effect of these compounds is being evaluated with a focus on mutagenicity and genotoxicity. However, this approach ignores the recent integration of new toxicological studies such as endocrine disorders, mixture toxicity, and toxicity to development. Although most of the environmental estrogen activity was recognized as "weak" for many years because of its inability to cause transcriptional effects, at present it has been proven that they are quite powerful initiators of signal cascades out of membranes (De Coster, van Larebeke, 2012).

The environmental hazard of these compounds lies in their ability to disrupt or modify the endocrine system of living organisms, which is central to their functioning, development and reproduction. They interact with a normally functioning endocrine system, modulate or block the action of natural hormones in the body, launch reactions identical to them thus affecting the synthesis, secretion, transport, binding, action, or elimination of natural hormones. They are active in very low doses, especially in foetuses and newborns. Endocrine-disrupting substances constribute significantly to the occurrence of cancer, neurological and behavioral disorders, the number of which has increased markedly in recent decades.

Hormones have different effects on the body at the different periods of life and this is due not only to age hormonal homeostasis, but also to the state of hormone-dependent organs (Hu et al., 2013; Hulin et al., 2014). The onset of puberty is characterized by a significant increase in the synthesis of estrogen by the ovaries due to changes in the "settings" of the hypothalamus, which "allows" a high concentration of the hormone in the blood.

Lipid peroxidation (LPO) is a universal biological mechanism constantly occuring in cellular membranes. Free radicals are mediators of signal transduction as a component of fundamental mechanism of inflammation, cytokines induction, proliferation, apoptosis, gene regulation of cellular security, chromatin remodulation, and poly(ADP-ribose) synthase activation. The recurrent peroxidation syndrome is a factor of the pathogenesis of several diseases: it serves as the basis for allocating them to the free radical pathology. The main components of the enzymatic antioxidation systems are superoxide dismutase (SOD) inactivating oxygen radicals, catalase, and glutathione redox system. Violation of the sensitive balance between free radicals and antioxidants can result in cell damage and trigger disorders of homeostasis (Lykholat et al., 2016). Exposure of xenoestrogen leads to strengthening of the generation of hydroxyl radicals with ensuing histopathological changes in the liver and kidneys, which can be explained either by estrogenic activity or the inclusion of different ways causing oxidative stress (Rashid et al., 2009). 
Acetylcholinesterase (AChE) plays a key role in the neurohumoral and synaptic transmission: it catalyzes the hydrolysis of acetylcholine in the cholinergic synapses and thus terminates this neurotransmitter act on cholinergic receptors responsible for the permeability of the postsynaptic membrane for ions. The system acetylcholine-acetylcholinesterase is one of the main parts of the autonomic nervous system that involves other mediator and modulator processes performing the reactions of effector organs on central nervous impulses.

Risks associated with nutritional influence of synthetic hormones have not been fully characterized yet, and publications give conflicting reports about long-term consequences of the use of such products (Omoruyi et al., 2013). Given the threat of contamination by chemicals with endocrine properties in the diet of pubertal children as a particularly sensitive population, an analysis of the risk regarding the occurrence of health problems in the future is required. The potential estradiol effects unrelated to reproductive functions require further study (Courant et al., 2008; Kummer et al., 2012; Hu et al., 2013; Hulin et al., 2014). The membrane acetylcholinesterase activity, cell stability, the anti-oxidative activity, and the generation of free radicals are the parameters used to characterize structural and functional changes in cells (Kujawa et al., 2014).

The aim of the present work was the study lipid peroxidation, antioxidant system components, and cholinergic neurotransmitter system in the organs of experimental rats of different ages for exposure to alimentary synthetic estrogen.

\section{MATERIALS AND METHODS}

The experiments were conducted on Wistar rats exposed to exogenous estrogen for 45 days. At the beginning of the experiment, threemonth-old pubertal animals (group 2) and sixmonth-old sexually mature rats (group 4) were involved. The control group consisted of intact animals of corresponding age (groups 1 and 3).

For the modelling of exogenous estrogen impact, the rats' food was treated with the drug
Sinestrol as stilbene derivative that differs from estrogen steroid hormones in chemical structure, but is similar to them in biological and medicinal properties at the rate of $2 \mathrm{mg} / \mathrm{kg}$.

Research materials were the brain, the liver, kidneys, and blood serum of rats. The objects were indices of TBA-active products, the total antioxidant activity, the activity of superoxide dismutase, glutathione peroxidase, glutathione transferase, glutathione reductase, glutathione content of the recovery, and AchE activity on standard methods.

The data were treated with standard methods of variational series estimation. The difference between the comparative values was considered significant at $p<0.05$.

\section{RESULTS}

The level of TBA-active products in the liver exceeded the control index by $26 \%$ in the group of pubertal rats and by $18.5 \%$ in mature females In kidneys, the accumulation of TBA-active products exceeded the control index by $10 \%$ (group 2) and by $21.5 \%$ (group 4). Activity of lipid peroxidation in the brain increased by $34 \%$ in experimental group 2 , and by $29.5 \%$ in group 4 . The TBKAP level exceeded the control index by $48 \%$ in the serum of 4.5 -month-old rats and by $51 \%$ in the serum of 7.5 -month-old rats (Table 1).

Glutathione is one of the most powerful cellular antioxidants. Glutathione deficiency is observed in numerous diseases including tumours. The mammalian liver is the main organ of glutathione synthesis. In the liver of the rats of group 2, the reductive glutathione content exceeded the corresponding indices of the control group by $35 \%$. In the group of older rats the increase amounted to $32 \%$.

Commonly, $80-90 \%$ of glutathione is captured and split by the kidneys due to extremely high activity of gamma-glutamyl transpeptidase. Under the influence of Sinestrol, a reductive depletion of the glutathione pool was observed in the kidneys. In the experimental rats (group 2), the reductive glutathione content was reduced by $28 \%$ compared with the control. 
Table 1. Indices of the brain tissue of rats of different age exposed to synthetic estrogen

\begin{tabular}{c|c|c|c|c}
\hline \multirow{2}{*}{\begin{tabular}{c} 
Indices \\
\cline { 2 - 5 }
\end{tabular}} & Group 1 & Group 2 & Group 3 & Group 4 \\
\hline $\begin{array}{c}\text { Reductive glutathione, } \\
\mathrm{mM} / \mathrm{g} \text { tissue }\end{array}$ & $221 \pm 11.05$ & $154.75 \pm 7.40^{\star}$ & $190 \pm 9.50$ & $203.25 \pm 10.16$ \\
\hline $\begin{array}{c}\text { Glutathione reductase, mnM/g tissue } \\
\text { Glutathione transferase, mkM/ min. g } \\
\text { protein }\end{array}$ & $195.2 \pm 9.76$ & $168.25 \pm 8.41^{\star}$ & $174 \pm 8.70$ & $200.5 \pm 10.03^{\star}$ \\
\hline $\begin{array}{c}\text { TBA-active products, } \\
\text { nM/g protein }\end{array}$ & $28.61 \pm 1.40$ & $38.26 \pm 1.90^{\star}$ & $24.26 \pm 0.12$ & $31.42 \pm 1.57^{\star}$ \\
\hline $\begin{array}{c}\text { Total antioxidant activity, standard } \\
\text { units }\end{array}$ & $34.35 \pm 1.71$ & $21.98 \pm 1.10^{\star}$ & $27.52 \pm 1.38$ & $17.17 \pm 0.85^{\star}$ \\
\hline $\begin{array}{c}\text { Superoxide dismutase optic unit/min. g } \\
\text { protein }\end{array}$ & $888.46 \pm 44.4$ & $764.08 \pm 38.2^{\star}$ & $543.91 \pm 27.2$ & $660.85 \pm 33.4^{*}$ \\
\hline $\begin{array}{c}\text { Glutathione peroxidase, mkM/ min. g } \\
\text { protein }\end{array}$ & $26.94 \pm 1.347$ & $28.02 \pm 1.40$ & $32.75 \pm 1.64$ & $38.97 \pm 1.95^{\star}$ \\
\hline
\end{tabular}

* Significant differences between the indices of control and experimental groups, $p \leq 0.05$.

In group 4 , the glutathione decline by $17 \%$ was recorded. The decrease of glutathione is an indicator of antioxidant system exhaustion.

In the blood serum of group 2 the glutathione content was $77 \%$ and in group $4-89 \%$ of the indices of the corresponding control groups.

In the brain of the control group of rats the glutathione index was $8 \%$ higher that the index of the relevant experimental group. The difference between the glutathione content in groups 3 and 4 was $8 \%$. In the brain of rats treated with hormones, the trend of growth of thiol compounds was observed.

In the liver of the experimental 4.5-monthold females, the glutathione reductase activity was $11.5 \%$ lower compared to the control. In 7.5-month-old animals, the enzyme activity was $48 \%$ higher than in intact females. In the kidneys of females of both experimental groups treated to alimentary estrogen exposure, activity of glutathione reductase did not differ significantly from the control. In the brains of the rats from group 2 inhibition of enzyme activity (13\%) was observed. In the brains of older females, the activating enzyme was $2 \%$. In the blood serum of the females from group 2, the glutathione reductase activity was $83 \%$, and in group $4-92 \%$ of the reference index.
Glutathione transferases play the primary role in the neutralization of secondary peroxidation products and other oxidized compounds. They are conjugated with glutathione basic and most toxic products of lipid peroxidation. These recovery compounds carried out by glutathione transferase prevent progression of peroxidation and the emergence of secondary metabolites. In the liver of 4.5-month-old and 7.5-month-old experimental animals the enzyme activity increased by $18 \%$ and $21 \%$, respectively.

There was a trend to activate enzymes in the kidney by $9 \%$ (group 2 ) and by $5 \%$ (group 4 ). The glutathione transferase activity was suppressed in the brain of younger animals by $10.5 \%$ and older ones by $6 \%$. In group 2 , the activity of the serum enzyme was inhibited by $20 \%$, in group 4 by $8 \%$.

SOD inactivates oxygen radicals occurring in biological reactions of the electron transfer, xenobiotics influence, or various diseases.

In experimental groups of pubertal and mature rats the trend of the increase in the SOD activity by $9 \%$ and $5 \%$, respectively, was determined in the liver. In the kidneys of pubertal rats the superoxide dismutase activity grew by $5 \%$. In the experimental group 4, enzyme activation was $17 \%$. In the brains of the group 2 rats, enzyme 
inhibition of $14 \%$ was observed while in the animals of group 4 the SOD activity increased by $21.5 \%$. The following results were obtained for blood serum: in younger female rats the enzyme activity increased by $32 \%$, in older ones by $15 \%$.

Reducing lipid peroxides in the corresponding alcohols and carrying out the splitting of hydrogen peroxide with the subsequent formation of water, glutathione peroxidase protects the body from oxidative damage.

In determining glutathione peroxidase using glutathione as a donor of $\mathrm{H}^{+}$, the activity decreased by $5 \%$ in experimental group 2 compared to the control index. In the liver of mature animals, no probable deviations from control were found. In the kidneys, the activity of enzyme inhibition was fixed and its extent was dependent on the age of the animals: in the experimental group of 4.5 -month-old rats it was $22 \%$, in 7.5 -month-old ones $14 \%$ of the intact groups. In the serum of groups 2 and 4 , the trend of activity increase by $12 \%$ and $5 \%$, respectively, was determined.

The study showed weak activation of glutathione peroxidase (by 4\%) in pubertal rats and an increase in the activity of the enzyme by $19 \%$ in the brain of mature females.

An investigation into the integral indicator of the antioxidant status - total antioxidant activity in the organs of female rats - indicated a different potential of protection systems depending on age. Thus, in kidneys, blood serum, and the liver an increase in the antioxidant system activity was marked: 4.5-month-old females by $4 \%, 21 \%$ and $18 \%, 7.5$-month-old animals by $30 \%, 29 \%$ and $14 \%$, compared to control groups. At the same time, the study of the brain showed quite a substantial inactivation of antioxidant index of $36 \%$ in the pubertal and of $38 \%$ in mature females.
In the AChE study, its activity was higher by $22 \%$ in the brains of younger rats compared to the control index. In the older group of experimental females, the enzyme activation by $15 \%$ was observed. When comparing enzyme index of 3-month- and 6-month-old animals, the activity increase by $5.3 \%$ was observed (Table 2 ).

In blood serum and liver tissue, the inhibition of enzyme activity was determined. In pubertal animals the indicator was significantly different from the corresponding control. For mature females the deviation of activity was less pronounced.

\section{DISCUSSION}

Alimentary estrogen exposure caused an amplification of lipid peroxidation in pubertal animals and mature females. There was a different degree of peroxidation intensification depending on the age and examined organs. The maximum excess of the indices of the intact rats was noted in serum. The kidneys were the most resistant to the impact of exogenous estrogen. In the brains and liver of younger females the reaction of the oxidative system exceeded the power of the response in the organs of sexually-mature animals.

A marked decrease of restored glutathione in the kidneys of the researched female groups demonstrates the risk of violations of the detoxification system. This can lead to an accumulation of free radicals that may trigger factors of various diseases in the future.

Age-dependant organ discreteness to changes in the activity of antioxidant enzymes was observed. This indicates an imbalance of enzymes of the glutathione system. Given the involvement of the glutathione system in the estrogen inactivation by conjugation in their

Table 2. The impact of nutritional effect of estrogen on the activity of acetylcholinesterase

\begin{tabular}{c|c|c|c|c}
\hline Investigated organ & Group 1 & Group 2 & Group 3 & Group 4 \\
\hline Blood serum, mM/mg protein/L & $4.52 \pm 0.31$ & $4.07 \pm 0.28^{*}$ & $4.74 \pm 0.36$ & $4.40 \pm 0.33$ \\
\hline Brain, $\mathrm{mM} / \mathrm{mg}$ protein/ min & $13.35 \pm 0.80$ & $16.23 \pm 0.92^{\star}$ & $14.06 \pm 0.95$ & $16.17 \pm 1.03^{\star}$ \\
\hline Liver, $\mathrm{mM} / \mathrm{mg}$ protein/ min & $2.77 \pm 0.21$ & $2.53 \pm 0.25^{\star}$ & $2.91 \pm 0.18$ & $2.73 \pm 0.22$ \\
\hline
\end{tabular}

* Significant differences between the indices of control and experimental groups, $p \leq 0.05$. 
reactions catalyzed by glutathione transferase, reducing its activity can result in the accumulation of intermediate metabolites and in damage to intracellular structures, mainly DNA.

An imbalance of SOD - glutathione peroxidase links - leads to an accumulation of peroxides, a symptom of endogenous intoxication more pronounced in younger females.

Admission of food hormones to the organism-caused changes of the prooxidant-antioxidant system in the brain and may be followed by a lesion of transmission of information signal. In the brain tissue, the reductive glutathione concentration is at a fairly constant rate. Therefore reducing tripeptide in the brain of a pubertal rat is a negative prognostic criterion of destruction of the afferent integrated system. The estrogen effect concerns the entire central nervous system and includes signaling pathways that intersect with other mediators, such as neurotransmitters and neuromodulator, thus affecting the processes associated with autonomic regulation, neuroprotection, and the like.

The accumulation of toxic metabolites can cause damage on both the cellular and organ levels.

The effects of AChE activity reduction by nutritional estrogen were fixed in the serum and liver. That could be caused by deterioration of the synthesizing function of liver, in particular by stagnation in the liver and kidneys. The enzyme activity was lower in pubertal females compared to mature rats, indicating a lower efficiency of neurotransmitter transmission in the corresponding cholinergic neurons in rats from the younger group. In the future, it can result in serious disturbances in the functioning of the body.

Preserving the enzyme activity on the cerebral cortex level proves the stability of this department. Activation of the enzyme in the cerebral cortex is an evidence of high functional plasticity of the brain tissue. At the same time, the tension in the cholinergic neurotransmitter system was higher in younger rats. Marked changes in their physiological importance are compensatory in nature; according to the experiment and to references in the literature
(Mariani et al., 2011) they are excessive for nerve cells of rat brain and result in a restructuring of the nervous tissue. This is a phenomenon that may trigger the emergence of new pathological states.

\section{CONCLUSIONS}

The state of peroxidation processes and AChE activities in females exposed to xenoestrogen, suggests the possibility of the restructuring of the functioning of mediator and enzyme systems, and of additional enhancement of pathological symptoms. It can be assumed that the effects listed above are able to initiate endocrine disorders, simulate reactions dependant on steroid hormone receptors and independant on the receptor of pathological processes. Regulation of different vectors provides for a different impact on the interaction cell-cell and cell-extracellular matrix and soluble factors. In the body, the identified phenomena can cause inhibition of apoptosis as one of the main mechanisms for removing damaged cells from the population. In the future, such phenomena may trigger a reduction of the potential of compensatory mechanisms, including adaptation and apoptosis, affect the regulation of brain homeostasis, and directly influence the intracellular processes during development and cell differentiation, thus compromising the health of the consumers.

Pubertal females were more sensitive to nutritional synthetic estrogen than mature animals, proving that age is another factor in xenoestrogen exposure. Due to the changes in the rates of reactions of detoxification but not of the metabolism of estrogen received into the organism, particularly with food, with age the animals were less susceptible to the effects of these substances.

Received 13 January 2017 Accepted 25 May 2017

\section{References}

1. Arditsoglou A, Voutsa D. Determination of phenolic and steroid endocrine disrupting 
compounds in environmental matrices. Environ Sci Pollut Res Int. 2008; 15(3): 228-36.

2. Boberg J, Taxvig C, Christiansen S, et al. Possible endocrine disrupting effects of parabens and their metabolites. Reprod Toxicol. 2010; 30: 301-12.

3. Cassidy A. Potential risks and benefits of phytoestrogen-rich diets. Int J Vitam Nutr Res. 2003; 73(2): 120-6.

4. Courant F, Antignac JP, Laille J, et al. Exposure assessment of prepubertal children to steroid endocrine disruptors. 2. Determination of steroid hormones in milk, egg, and meat samples. J Agric Food Chem. 2008; 14, 56(9): 3176-84.

5. Courant F, Antignac JP, Maume D, et al. Determination of naturally occurring oestrogens and androgens in retail samples of milk and eggs. Food Addit Contam. 2007; 24(12): 1358-66.

6. Darbre PD, Charles AK. Environmental oestrogens and breast cancer: evidence for combined involvement of dietary, household and cosmetic xenoestrogens. Anticancer Res. 2010; 30: 815-27.

7. De Coster S, van Larebeke N. Endocrinedisrupting chemicals: associated disorders and mechanisms of action. J. Environ. Public Health. 2012: 696-713.

8. Dhaini HR, Nassif RM. Exposure assessment of endocrine disruptors in bottled drinking water of Lebanon. Environ Monit Assess. 2014; 186(9): 5655-62.

9. Hercegová A, Dömötörová $\mathrm{M}$, Matisová E. Sample preparation methods in the analysis of pesticide residues in baby food with subsequent chromatographic determination. J Chromatogr A. 2007; 15, 1153(1-2): 54-73.

10. Hu J, Du G, Zhang W, et al. Short-term neonatal/prepubertal exposure of dibutyl phthalate (DBP) induced advanced puberty timing and affected hypothalamic kisspeptin/GPR54 expression differently in female rats. Toxicology. 2013; 9(20): 244-8.

11. Hulin M, Bemrah N, Nougadère A, et al. Assessment of infant exposure to food chemicals: the French Total Diet Study design. Food Ad- ditives and Contaminants: Part A. 2014; 31(7): 1226-39.

12. Kolf-Clauw M, Ayouni F, Tardieu D, Guerre P. Variations in zearalenone activation in avian food species. Food Chem Toxicol. 2008; 46(5): 1467-73.

13. Kujawa J, Pasternak K, Zavodnik I, et al. The effect of near-infrared MLS laser radiation on cell membrane structure and radical generation. Lasers Med Sci. 2014; 29(5): 1663-8.

14. Kummer S, von Gersdorff G, Kemper MJ, Oh J. The influence of gender and sexual hormones on incidence and outcome of chronic kidney disease. Pediatr Nephrol. 2012; 27(8): 1213-9.

15. Lykholat T, Lykholat O, Antonyuk S. Immunohistochemical and biochemical analysis of mammary gland tumours of different age patients. Cytol \& Genet. 2016; 50(1): 32-41.

16. Mariani A, Jeandel C, Paris F, Ecochard R. Puberty and pubertal growth dynamics in children with idiopathic short stature. J. Pediatr. Endocrinol Metab. 2011; 24(6): 319-25.

17. Massart F, Saggese G. Oestrogenic mycotoxin exposures and precocious pubertal development. Int J Androl. 2010; 33(2): 369-76.

18. McEwen BS. Sex, stress and the brain: interactive actions of hormones on the developing and adult brain. Climacteric. 2014; 17(2): 18-25.

19. Meulenberg EP. Phenolics: occurrence and immunochemical detection in environment and food. Molecules. 2009; 19; 14(1): 439-73.

20. Omoruyi IM, Kabiersch G, Pohjanvirta R. Commercial processed food may have endocrine-disrupting potential: soy-based ingredients making the difference. Food Additives and Contaminants: Part. A 2013; 30(10): 1722-7.

21. Petrone AB, Simpkins JW, BarrTL. $17 \beta$-estradiol and inflammation: implications for ischemic stroke. Aging Dis. 2014; 1; 5(5): 340-5.

22. Rashid H, Ahmad F, Rahman S, et al. Iron deficiency augments bisphenol A-induced oxidative stress in rats. Toxicology. 2009; 256: 7-12. 
23. Rochester JR. Bisphenol A and human health: a review of the literature. Reprod. Toxicol. 2013; 42: 132-55.

24. Shearwood AM, Chia T, Davies SM, et al. Estrogen-mediated regulation of mitochondrial gene expression. Mol Endocrinol. 2015; 29(1): 14-27.

25. Tomar RS, Shiao R. Early life and adult exposure to isoflavones and breast cancer risk. J. Environ. Sci. Health C Environ. Carcinog Ecotoxicol Rev. 2008; 26(2): 113-73.

26. Wielogorska E, Elliott CT, Danaher M, Connolly L. Validation and application of a reporter gene assay for the determination of estrogenic endocrine disruptor activity in milk. Food Chem Toxicol. 2014; 69: 260-66.

27. Wielogórska E, Elliott CT, Danaher M, Connolly L. Endocrine disruptor activity of multiple environmental food chain contaminants. Toxicol In Vitro. 2015; 29(1): 211-20.

\section{Oleh Yermishev, Tatyana Lykholat,} Olena Lykholat

\section{MAISTINIO SINTETINIO ESTROGENO POVEIKIS SKIRTINGO AMŽIAUS ŽIURKIŲ LĄSTELĖS KOMPENSACINIAM MECHANIZMUI}

\section{Santrauka}

Daugelis teršalų yra susiję su jų galimu estrogeniniu poveikiu, todèl klasifikuojami kaip endokrini- nès sistemos veiklą trikdantys junginiai, įskaitant daugelị organinių junginių. Estrogenai yra moteriški lytiniai hormonai, reguliuojantys specifines lytines funkcijas. Juos gamina kiaušidžių folikulai, placenta, iš dalies antinksčiu žievè ir sèklidès. Ksenoestrogenai yra pramoninès cheminès medžiagos, naudojamos polikarbonatinio plastiko, epoksidinès dervos, maisto pakuočiuc ir dangu, odontologinių hermetikų, antimikrobinių preparatų, medikamentų, asmens higienos priemonių gamybai. Šio tyrimo metu buvo tiriama skirtingo amžiaus eksperimentinių žiurkių, paveiktų maistiniu sintetiniu estrogenu, lipidų peroksidacija, antioksidacinès sistemos komponentai ir cholinerginè neuromediatorių sistema. Atsižvelgiant ị peroksidacijos procesus ir acetilcholinesterazès aktyvumą patelių organizme panaudojus ksenoestrogenus, galima daryti prielaidą dèl galimo mediatoriaus ir fermentinès sistemos restruktūrizuojančio funkcionavimo, papildomai stiprinančio patologinius simptomus. Nustatyta, kad amžius yra vienas iš ksenoestrogenų poveikio veiksnių, nes bręstančios patelès buvo daug jautresnès maistiniam sintetiniam estrogenui nei subrendę gyvūnai. Dẻl reakcijų greičio pokyčių, atsiradus detoksikacijai, bet ne metabolizmui, ypač su maistu estrogeną gaunantys gyvūnai su amžiumi buvo mažiau jautrūs minètam poveikiui.

Raktažodžiai: ksenoestrogenas, lipidų peroksidacija, antioksidacinè sistema, cholinerginis reguliavimas, amžius 